\title{
The Effect of Teaching Strategies and Curiosity on Students' Achievement in Reading Comprehension
}

\author{
Busmin Gurning ${ }^{1} \&$ Aguslani Siregar ${ }^{1,2}$ \\ ${ }^{1}$ Postgraduate School at State University of Medan, Medan (North Sumatera), Indonesia \\ ${ }^{2}$ Alumnae of Postgraduate School at State University of Medan, North Sumatera, Indonesia \\ Correspondence: Busmin Gurning, Postgraduate School at State University of Medan, Medan (North Sumatera), \\ Indonesia. E-mail: profbusmingurning@gmail.com
}

\author{
Received: August 22, 2017 Accepted: October 15, 2017 Online Published: October 19, 2017 \\ doi: 10.5539/elt.v10n11p191 URL: http://doi.org/10.5539/elt.v10n11p191
}

\begin{abstract}
The objectives of this study were to find out whether 1) students' achievement in reading comprehension taught by using INSERT strategy was higher than those taught by using SQ3R strategy, 2) Students' achievement in reading comprehension having high curiosity was higher than those having low curiosity, 3) there was an interaction between teaching strategies and curiosity on students' achievement in reading comprehension. Quasi experimental research with factorial design $2 \times 2$ was used in this study. The total number of sample were 76 persons, with 38 students of each class (experimental and control classes). The first class was treated by using INSERT strategy and the second class was treated by using SQ3R strategy. The students were also divided into two groups based on curiosity, such as high and low curiosity. The data were collected through reading comprehension by using objective test, whereas for aptitude like curiosity, questionaire was used. The data were then analyzed by applying two-way ANOVA at the level of significance at $\alpha=0.05$. The data analysis revealed that (1) students' achievement in reading comprehension taught by using INSERT was higher than those taught by using SQ3R, with $\mathrm{F}_{\text {obs }}(27.32)>\mathrm{F}_{\text {tab }}$ (3.98), (2) students' achievement in reading comprehension with high curiosity was higher than those students with low curiosity with $F_{\text {obs }}(6.92)>F_{\text {tab }}(3.98)$, (3) there was an interaction between teaching strategies and students' curiosity on students' achievement in reading comprehension with $\mathrm{F}_{\text {obs }}(15.43)>\mathrm{F}_{\text {tab }}$ (3.98). Tuckey test was then applied to verify the interaction between each sample comparison.
\end{abstract}

Keywords: curiosity, INSERT, SQ3R, students' achievement, and reading comparison

\section{Introduction}

Reading is one of the important skill to master by the students besides writing, speaking, and listening in order to be able to use English in global to communicate and to get information well. Hammer (2003) declared that Reading has different meaning for different people. Some people read to get feeling and pleasure while the others read to get ideas and information. For students, particularly they are reading to have general understanding. It means that when the students are reading the texts, they try to comprehend the words arrangement, they engage with what they are reading to respond the content and to catch the message conveyed.

Learning to comprehend the texts nowadays is a complicated task to do for students of Senior High School since Kurikulum Tingkat Satuan Pendidikan (KTSP) requires them to know various text genres based on their levels, for example; Recount, Narrative, Procedure etc. By knowing those genres, hopefully they are being informational literate in terms of knowledge elevation in accordance with their need in their lives as stated in content standard (Standar isi) of KTSP. Badan Standar Nasional Pendidikan (BSNP) will formulate genre-based questions to test the students' reading comprehension in state examination or Ujian Nasional (UN). Even, reading comprehension takes dominant position among the other kind of questions. From 50 questions tested only 15 questions are aimed at testing listening skill while the rests are aimed at testing reading comprehension skill.

Moreover, a deeper level of curiosity by creating the problem situation which can be resolved only by knowledge-seeking behavior states (Keller, in Driscoll, 2005, p. 296). When the students are exposed to INSERT and SQ3R strategies in comprehending text, they, actually are treated to be information seekers since they must 
be aware of what they know and what they believe and they must confront what they know and believe with the information conveyed by the writer in a text.

Based on the explanation above, it is believed that teaching strategies and the level of curiosity will affect achievement in reading comprehension. Therefore, in this study the researcher is interested to find out the effect of INSERT and SQ3R strategies in improving the students' reading comprehension for those who have high and low curiosity.

In line with the problems, the objectives of the study are to find out whether the students' achievement in reading comprehension taught by using INSERT strategy is higher than taught by using SQ3R strategy; to find out whether students' achievement in reading comprehension with high curiosity is higher than students' achievement in reading comprehension with low curiosity and to find out whether there is a significant interaction between teaching strategies and students' curiosity on students' achievement in reading comprehension.

Theoretically, it is able to give positive contribution for teaching in overcoming problem in reading through the value of findings in the area of teaching reading. Moreover, this study will extend students' knowledge, develop their knowledge of decoding skills and expand their ability to comprehend what they are reading.

Brown (2004) states the achievement is the process of developing skill or knowledge. The most common type of achievement is a standardized progress in developing the measurable skill or knowledge learned in a given grade level, usually through planned instruction, such as training or classroom instruction. The achievement is the measurable process, a more general and stable cognitive trait.

Moreover, Anderson (2001) uttered reading comprehension is also meant as the process of constructing meaning by coordinating a number of complex processes that include word reading, word and world knowledge, and fluency.

The types of text that would like to be used as the sample of reading comprehension is exposition text. Since the text often appears in National Examination and mostly the students give the wrong answer to the questions on this type of the text. The students' achievement in reading comprehension will be tested deals with taxonomy of comprehension, they are, literal, inferential and critical comprehension. The three types of reading comprehension shown in the following.

Literal comprehension involves what the author is actually saying. The reader needs to understand ideas and information explicitly stated in the text including what, who, where, and when of the passage. The readers, who are at this level, believe that they have adequately comprehended text if they can recognize the content words and can understand most of the sentences. Generally, the readers at this level only identify lists of facts, definitions of concepts and other easily memorized materials.

Inferential comprehension refers to the ability of the readers to establish, guess correctly the logical inference of the authors. The readers, at this level, must be able to order authors' ideas coherently and find out the intended messages conveyed by the authors in the passage. Inferential comprehension is harder than literal comprehension for the readers are not only recognize the author's ideas stated explicitly in the text, but they have also to be able to guess the author's intention either explicitly or implicitly stated in the text. Inferential comprehension includes text connecting inferences which are required to integrate information from different parts of the text and to establish coherency and gap filling inferences in which information from outside the text (general knowledge) is incorporated with information in the text to fill in gaps in missing details and to help formulate a coherent representation of the text as a whole (Danielle, 2007).

Critical comprehension refers to deep comprehension of understanding a text. Critical comprehension emphasizes thinking ritually about text meaning and intentionally making connection between text and relevant knowledge of the world beyond that text. Fisher (2001: 8) relates critical comprehension to critical thinking. It includes how to identify the elements in a reasoned case, especially reason and conclusions, identify and evaluate assumptions, clarify and interpret the ideas and expressions, recognized unstated assumption and values, render accurate judgment about specific things, evaluate arguments of different kinds, analyze, evaluate, and produce explanations, draw inferences, and produce arguments. So, among all, critical comprehension is the most difficult level to reach because at this level, the readers arrived at evaluative stage.

In relation to genre, Martin (1999) states that genre is a communication activity having and orienting goal. Then, Swales (1990) simply defines genre is a communication event in which the members have a set of communication goal. By referring two statements above, it can be said that genre is a process of communication which has a certain goal (goal oriented) for its members in a certain event of communication due to certain social context. Genre is a 
matter of communication event by social context. Consequently, the different social context then, tends to lead to different genre. In line with the concept of genre, then, Christie dan Martin (2000) adds that genre is the particular usage of the language in a certain social circumstance such as interview genre, media genre, or advertisment genre, and so forth.

Genre is a term used to describe the classification of written materials. Genre can be defined as a culturally specific text type which results from using language (written or spoken) to accomplish something. Gerot (1994) stated that there are 13 types of genre and each genre has certain purpose, certain stages, and certain linguistic features.

\subsection{Strategy of Teaching}

The INSERT strategy is a strategy that help students interact with the text to clarify their thinking. INSERT gets readers interacting with the text by "inserting" their thought into the ideas proposed by the text to monitor their comprehension and make decision such as, "I knew that," "I don't understand," and "That's really important."

The Interactive Notation System for Effective Reading and Thinking (INSERT) was originally created by Vaughn and Estes (1986); it uses symbols or notations such as a check mark or a plus sign as a way for the reader to respond to the text while reading. This strategy helps students to activate background knowledge. It used by relating what they know previously to new information that is found in the text. It also helps them to identify what they do not know or are confused about during reading. It means that through this strategy, we know the students' prior knowledge about the text by seeing their symbols' chosen. Also we may know their ability and confusing in the text by their symbols.

After all students have read, recorded symbols, and created their own insert summary charts, they compare their charts with one or two peers. Discussion based on these charts will help to clarify information for students. This strategy is most powerful when students create a conceptually based map from their INSERT chart. After comparing their INSERT summary charts, students might reorganize their post-notes to reflect how the information they have recorded is related, producing a concept map or graphic organizer.SQRRR or "SQ3R" is a reading comprehension strategy named for its five steps: survey, question, read, recite, and review. The method was introduced by Francis Pleasant Robinson. The strategy offers a more efficient and active approach to reading textbook material. SQ3R will help the students build a framework to understand their reading assignment. It was created for college students, but is extremely useful for the students as well.

Since it involves reviewing, SQ3R must be used with a text that is unfamiliar to the students. However, students should have some background knowledge. The teacher needs prepare for the activity ahead of time by reading the book and deciding in advance where the stopping points will be for each section.

Meanwhile, Thomas (1991) argued that INSERT strategy assists the reader in maintaining sustained engagement with text; it promotes meta-cognitive activity in the reader, and therefore is a good choice to use with struggling readers. By using the INSERT's note, students automatically are able to flash back to the previously reading about something and relate to the new one. The note of the INSERT is also describes the students' ability in comprehending the text. If they have knowledge about something before, they answer the questions directly without to fill all the note of INSERT and it can help them not to waste the time. This strategy also helps them when they have their own textbook, and make them easy to interpret the content of the book itself. Saricoban (2005) has conducted a research which is in the line the INSERT strategy on the study of INSERT Reading Strategy Employed by ELT at the Advance Level and the result prove that INSERT reading strategy has good application to advance level.

The use of SQ3R is also important as the strategy of reading. The process of SQ3R strategy begins with guiding and stimulating students' survey through the use of questions. The teacher gives examples of how to make reciting. Pose open-ended questions, and encourage students to state their reciting, valuing and supporting all ideas. The teacher repeats this process until students have read each section of the passage and verifies or modifies the survey made at the beginning of the lesson. SQ3R develop comprehension by activating students' background knowledge, having them survey understand title, and answer question. These strategies were suggested in the literature and by knowledgeable others, and related to personal interest. It helps student interpret, analyze, and deeper their understanding without reciting; students' comprehension can be difficult to develop.

Curiosity is defined as a disposition to inquire, investigate or seek after knowledge. It is simply to frame of mind in which you went to learn more about something it also provides the source of internal motivation that comprises the foundation of education. Berlyne (1998) stated that curiosity is defined as a need, thirst or desire for knowledge. The concept of curiosity is a control to motivation. The terms can be used as both a description 
of specific behavior as well as hypothetical construct to explain the same behavior; he also argues that the curiosity is a motivational prerequisite for exploratory behavior.

\section{Method}

The design used in this study was quantitative approach with an experimental design. The experimental design served two functions: it established the conditions for the comparison required by the hypotheses testified and it enabled the experimental statistical analysis more meaningful in interpretation (Ary, 2011).

\subsection{Research Design}

This study was carried out by using factorial design $2 \times 2$ in order to compare two teaching strategies (such as INSERT and SQ3R) and two types of students' curiosity (high and low). In addition, there were three variables in this study, namely two independent variables (INSERT and SQ3R strategies), and moderator variable was students' curiosity and one dependent variable is called reading comprehension. The research design was presented on Table 1. In doing the research internal and external validity was controlled as good as possible.

Table 1. Factorial research design $2 \times 2$

\begin{tabular}{lll}
\hline $\begin{array}{l}\text { Teaching Strategies }(\mathrm{A}) \\
\text { Students' Curiosity(B) }\end{array}$ & INSERT Strategy $\left(\mathrm{A}_{1}\right)$ & \\
\hline High $\left(\mathrm{B}_{1}\right)$ & & $\mathrm{A}_{2} \mathrm{~B}_{1}$ \\
Low $\left(\mathrm{B}_{2}\right)$ & $\mathrm{A}_{1} \mathrm{~B}_{1}$ & $\mathrm{~A}_{2} \mathrm{~B}_{2}$ \\
\hline
\end{tabular}

Note:

$\mathrm{A}_{1} \mathrm{~B}_{1}$ : Students who have high curiosity are taught by using INSERT strategy.

$\mathrm{A}_{2} \mathrm{~B}_{1}$ : Students who have high curiosity are taught by using SQ3R strategy.

$\mathrm{A}_{1} \mathrm{~B}_{2}$ : Students who have low curiosity are taught by using INSERT strategy.

$\mathrm{A}_{2} \mathrm{~B}_{2}$ : Students who have low curiosity are taught by using SQ3R strategy.

\subsection{Sampling Procedures}

\subsubsection{Population and Sample}

The research was conducted at SMA Swasta RK Serdang Murni Lubuk Pakam North Sumatra. This school was known much because this place was place to work. The population of this study were all the students in the XI grade academic year 2016/2017 on the first semester. The total number of population was 152 students in four classes. Then, two classes were chosen as the source of sample of the study.

Multi-cluster random sampling was the technique of taking sample of group of subjects that were selected by chance without bias. It was used only to consider two major in grade XI selected as the representative population. The first group was IPA1 as the experimental group, taught by using INSERT strategy. Meanwhile, the second group was IPA2, as the control group taught by using SQ3R strategy.

\subsubsection{Instruments of Research}

The validated instruments used in this research were objective test and questionaire. The objective test was used to test the students' reading comprehension and questionaire was constructed to test students' curiosity. There were fourty items for testing reading comprehension (which is related to literal, inferential, and critical comprehension) and twenty items questionaire for testing aptitude by using Likert Scale.

\subsubsection{Procedure of the Treatment}

The treatment was conducted in both experimental and control classes with have the same horizon of teaching. There are two teachers have the same experience in teaching, they have the same degree, teaching experience, and sex. The difference is on the use of teaching strategies. The first teacher applied INSERT strategy in group one, and the second teacher applied SQ3R strategy in the group two. The students of two classes have the same characteristics. They were in the same school, the same grade, and range of age. The process of the treatment was carried out twice a week and it took 90 minutes for each treatment. The researcher explained the steps of teaching strategies (INSERT and SQ3R) to the teachers who taught in the two classes and make sure that students in both groups did not know that they were treated in different ways. The teachers had treated the 
sample in six meeting; it was five weeks to accomplish the treatment in the two classes, and it end up by giving test to them.

The second variable was students' curiosity. The two classes were divided by the two students' curiosity, they are high and low curiosity for both classes. Whereas for low level of students' curiosity, the students' achievement taught by using SQ3R strategy was higher than students' achievement taught by using INSERT stategy. Curiosity is defined as a disposition to inquire, investigate or seek after knowledge. It is simply to frame of mind in which you went to learn more about something it also provides the source of internal motivation that comprises the foundation of education. Berlyne (1998) stated that curiosity is defined as a need, thirst or desire for knowledge.

\section{Results}

\subsection{Data Analysis}

The analysis of data had been used in this research was two-way Analysis of Variance (ANOVA) at level of significance $\alpha=0.05$. It was used to test the three hypotheses. Before applying the two way ANOVA, there were two requirements namely the normality and homogenity of the test should be fullfiled. Normality was tested by using Liliefors - test and homogeneity was tested by using $\mathrm{F}$ - test and Barlet - test.

\subsection{Results of Research}

The results of research could be seen from data shown in the following table. The students' achievement in reading comprehension were related to many aspects of statistical values in the interaction between reading strategies and students' curiosity as shown the highest and lowest score, range, median, mode, standard deviation and variance. The values are presented in Table 2 .

Table 2. Summary of research data description

\begin{tabular}{lllllllll}
\hline $\begin{array}{l}\text { Statistical } \\
\text { Values }\end{array}$ & A1 & A2 & B1 & B2 & A1B1 & A1B2 & A2B1 & A2B2 \\
\hline $\mathrm{N}$ & 38 & 38 & 38 & 38 & 19 & 19 & 19 & 19 \\
Highest Score & 37 & 34 & 93 & 71 & 37 & 29 & 33 & 29 \\
Lowest Score & 20 & 20 & 74 & 54 & 27 & 20 & 20 & 20 \\
Mean & 28.08 & 26.89 & 81.63 & 63.68 & 31.63 & 24.58 & 26.58 & 25.58 \\
Median & 28.00 & 27.50 & 80.00 & 64.50 & 31.00 & 25.00 & 26.00 & 26.00 \\
Mode & 28.00 & 28.00 & 76.00 & 64.00 & 30.00 & 27.00 & 32.00 & 29.00 \\
Standard & 4.54 & 4.09 & 5.62 & 4.39 & 2.73 & 3.06 & 4.35 & 3.06 \\
Deviation & & & & & & & & \\
\hline Variance & 20.57 & 16.69 & 31.59 & 19.25 & 7.47 & 9.37 & 18.92 & 7.37 \\
\hline Notes: & & & & & & & &
\end{tabular}

A1 : Group of students taught by using INSERT Strategy.

A2 : Group of students taught by using SQ3R Strategy.

B1 : Group of students with high curiosity.

B2 : Group of students with low curiosity.

A1B1 : Group of high curiosity taught by using INSERT Strategy.

A1B2 : Group of low curiosity taught by using INSERT Strategy.

A2B1 : Group of high curiosity taught by using SQ3R Strategy.

A2B2 : Group of low curiosity taught by using SQ3R Strategy.

The following is the summary of the two way ANOVA computation which contained the variance related to the score of means, teaching strategies, students' curiosity, interaction, error, and means of treatment. By looking at this description of the analysis of variance, it is easier to take into account the analysis related to two-way ANOVA as shown in the following. 
Table 3. Summary on calculation result of two way ANOVA

\begin{tabular}{llllll}
\hline Variance & $\begin{array}{l}\text { Dk } \\
(\mathrm{Df})\end{array}$ & Sum of Squares & Mean Square & $\mathrm{F}_{\text {observed }}$ & $\begin{array}{l}\mathrm{F}_{\mathrm{t}} \\
\mathrm{A}(\alpha)=0.05\end{array}$ \\
\hline Teaching Strategies & 1 & 308 & 308 & 27.32 & 3.98 \\
Students' Curiosity & 1 & 78 & 78 & 6.92 & 3.98 \\
Interaction & 1 & 174 & 174 & 15.43 & 3.98 \\
Error & 72 & 812 & 11.27 & - & - \\
Means of treatment & 1 & 557155 & - & - & - \\
Total & 76 & 57155 & - & - & - \\
\hline
\end{tabular}

This summary on computation result of the two-way ANOVA could be used to verify or to describe testing hypotheses. By considering the idea of above table, it could be related to the testing of hypotheses. Based on this testing hypotheses, it could be concluded that hypotheses were really verified. The value of obserbed $\mathrm{F}$ exceeds the value of $F$ from table in the three variances (teaching strategy (27.32), curiocity (6.92), and interaction (15.43) whereas the value of $\mathrm{F}$ from table was merely 3.98 for three variances. It could be concluded that the three hypotheses were verified at alpha 0.05 , as seen in the following.

1) The students' achievement in Reading Comprehension taught by using INSERT strategy was higher that those taught by using SQ3R strategy was really true,

2) The students' achievement in Reading Comprehension with high curiosity got higher than those low curiosity was really true,

3) There is an interaction between teaching strategy and students' curiosity in reading comprehension was really true.

\section{Discussion}

\subsection{Students' Achievement in Reading Comprehension Taught by Using INSERT Strategy is Higher than Those Taught by using SQ3R Strategy}

The INSERT strategy is a strategy that can help students interact with the text to clarify their thinking. INSERT gets readers interacting with the text by "inserting" their thought into the ideas proposed by the text to monitor their comprehension and make decision such as, "I knew that," "I don't understand," and "That's really important."

The Interactive Notation System for Effective Reading and Thinking (INSERT) was symbol or notation such as a check mark or a plus sign as a way for the reader to respond to the text while reading (Vaughn \& Estes, 1986). This strategy helps students activate background knowledge. This strategy helps students activate background knowledge. It was used by relating what they know previously to new information that is found in the text. It also helps them identify what they do not know or are confused about during reading. It means that through this strategy, we know the students' prior knowledge about the text by seeing their symbols' chosen. Also we may know their ability and confusing in the text by their symbols. Thomas (1991) argued that INSERT assists the reader to maintain sustained engagement and promotes metacognitive activity in the reader; it is able to flashback to the previously reading something new.

After all students have read, recorded symbols, and created their own insert summary charts, they compare their charts with one or two peers. This strategy is most powerful when students create a conceptually based map from their INSERT chart. After comparing their INSERT summary charts, students might reorganize their post-notes to reflect how the information they have recorded is related, producing a concept map or graphic organizer. SQ3R is a reading comprehension strategy named for its five steps: survey, question, read, recite, and review. The strategy offers a more efficient and active approach to reading textbook material (Heilman, 2005). SQ3R will help the students build a framework to understand their reading assignment. It was created for college students, but is extremely useful for the students as well. Since it involves reviewing, SQ3R must be used with a text that is unfamiliar to the students. However, students should have some background knowledge. The teacher needs prepare for the activity ahead of time by reading the book and deciding in advance where the stopping points will be for each section. 
INSERT and SQ3R are two strategies in reading and teaching reading. Based on the data that the students' achievement taught by using INSERT strategy was higher than that taught by using SQ3R strategy in teaching reading comprehension. It was helped by the symbols and notations as check and mark as a way of teacher to respond to the text while they are reading (Vaughn \& Estes, 1986).

Artis (2008) states the significance and usefulness of SQ3R as: "Because students can independently learn the basics of the course via reading, it reduces the need for instructor monologues (passive learning) to cover that information" .He argues that this enables students to be more active and involved in their learning. He maintains that SQ3R helps students change their negative impression about reading textbooks. Artis further states that SQ3R introduces a diverse set of mega cognitive reading techniques in a way students can easily understand and implement.

\subsection{Students' Achievement in Reading Comprehension with High Curiosity is higher than Those Low Curiosity}

Curiosity is one of personal traits that plays very important to have by students in comprehending a text. Curioucity is defined as a need and it controlled by a motivation (Berlyne, 1997). The more curious the students are, the better they comprehend the text. The students with high curiosity will have great desire to questions the gaps in the learning, seek exploratory information and knowledge, answer particular questions and good attention in learning while the students with low curiosity will perform contrastingly (Dweek, 2006).

The result of the two way ANOVA calculation shows that curiosity significantly affects students' achievement in reading comprehension. The total mean indicated that the students' achievement with high curiosity is higher than students those have low curiosity. The total mean indicated that the students with high curiosity get higher achievement than the students with low curiosity. It is because the students with high curiosity tend to be more active in learning, more enthusiastic with the tasks given by teacher, and never feel bored to retry in their attempt to achieve maximal result in reading comprehension.

On the other hand, the students with low curiosity attempt less than the students with high curiosity. They involve less in the learning process, do not like challenging actions and teaching learning process that needs much thinking action. They do less attempt in achieving the maximal result in learning reading comprehension. This condition can be observed directly during the teaching learning process. As matter of result of their curiosity, they get lower achievement in reading comprehension than those have high curiosity. The group of students with high curiosity has higher achievement than the group of students with low curiosity. The students with high curiosity get higher result in reading comprehension than the students with low curiosity. Thus, it is clear that different level of students' curiosity affect the students' abilities in reading comprehension (Driscall, 1994).

Kashdan (2009) identified some characteristics of students with high curiocity toward learning, they are: 1) students always interested in new things and processing an open and receptive attitude toward whatever is the target of attention, 2) students will devote more attention to an activity, remember information better and more likely to persists on talks until goals are met, 3) students will have the ability to effectively cope with of make sense of the novelty, ambiguity and uncertatinty being confronted during explorations.

Meanwhile, characteristics of students with low curiocity toward learning are; 1) students have sequencing difficulties are evidenced in a failure to grasp time concepts, and 2) students will lose track of assigment and attendance to concertarte, and students have experience cognitive confusion in the presence of distracting stimuli, demonstrate poor organizational skills, and fit it hard to refocus after losing concentration.

\subsection{The Interaction between Teaching Strategies and Curiosity on Students' Achievement in Reading Comprehension}

The result of two way ANOVA calculation indicated that there is a significant interaction between teaching strategies and curiosity. Teaching strategy and curiosity are two of several important factors that influence learning achievement. Thus the interaction was computed in order to find out the better achievement in reading comprehension among the cells. It indicated that the students were taught by using INSERT strategy with high curiosity and the students that were taught by using INSERT strategy with low curiosity have the most significant difference among others. The students that were taught by using INSERT with high curiosity have higher achievement in reading comprehension than the students that were taught by using SQ3R strategy with high curiosity. On the other hand, the students with low curiosity get higher students' achievement in reading comprehension if they were taught by using SQ3R strategy than they were taught by using INSERT strategy.

The interaction could be continued to the use Tuckey test in order to verify the interaction itelf. The Tuckey test described and showed that sudents' lower curiosity is matching to the use of SQ3R and students' higher curiosity is also matching to the use of INSERT strategy in teaching reading comprehension. 


\section{Acknowledgments}

Based on the data analysis, some conclusions are derived from meaningful discussion of this study as in the following: INSERT strategy and SQ3R strategy give the different effect on students' achievement in reading comprehension. Students' achievement in reading comprehension taught by using INSERT strategy is higher than those taught by using SQ3R strategy. The students' achievement in reading comprehension with high curiosity is higher than that with students with low curiosity; There is a significant interaction between teaching strategy and curiosity on students' achievement in reading comprehension. Students have high curiosity showed significant effect on their achievement in reading comprehension if they were taught by using INSERT strategy. While students have low curiosity showed significant effect on their achievement in reading comprehension if they were taught by using SQ3R strategy.

\section{References}

Anderson, W. (2001). A Taxonomy for Learning, Teaching, and Assessing. England: Longman.

Artis, A. B. (2008). Improving marketing Students Reading Comprehension with the SQ3R Method. Journal of Marketing Education, 30, 130-137. https://doi.org/10.1177/0273475308318070

Ary, D., Lucy, C. J., \& Asghar, R. (1979). Introduction to Research in Education. (2nd Ed). Holt. Rinehart and Winston.

Berlyne, D. E. (1960). Conflict, Arousal, and Curioucity. New York. McGraw Hill. https://doi.org/10.1037/11164-000

Berlyne, D. E. (1998). Curiosity and Learning. Chicago: Rand McNally.

Brown, H. D. (2004). Principle of Language learning and Teaching (5th Edition). London: Longman.

Christie, F. dan J. R. Martin. (2000). Genre and Institutions:Social Process in the Workplace and School. New York: Continum.

Danielle, S. (2007). Readig Comprehension, Strategies: Theories, Intervention and Technologies. New Jersey: Lawrence Elbaum Associates.

Driscall, M. P. (1996). Psychology of Learning for Instruction. Boston: Allyn and Bacon.

Dweck, C. (2006). Mindset: The New Psychology of Success. New York: Random House.

Fisher, A. (2003). Critical Thinking: An Introduction. Cambridge: Cambridge Univerity Press.

Gerot, L., \& Peter, W. (1994). Making Sense of Functional Grammar. Australia: Antipodean Educational Enterprises.

Harmer, J. (2003). The Practice of English Language Teaching. London: Longman. https://doi.org/10.1093/elt/57.3.288

Jonathan, R. (2012). The Power of Curiosity. UK: RSA.

Kahdan, T. (2009). Curious? Discover the missing ingredient to a fulfilling life. New York, NY: Harper Collins.

Loewenstein, G. (1994). The Psychology of Curiosity. A Review and Reinterpretation, 116(1) 75-98.

Martin, J. R. (1999). Factual Writing: Exploring and Challenging Social Reality. Melbourne: Deakin University Press.

Swales, J. M. (1990). Genre Analysis English in Academic and Research Settings: Cambridge: Cambridge University Press.

Thomas, L. V. (1991). The Effects of inserted questions and story retelling on comprehension of narrative text by fourth graders. Dissertations from Pro Quest. Paper 2986. http://scholarlyrepository.miami.edu/dissertations/2986

Vaughn, J., \& Estes, T. (1986). Reading and Reasoning Beyond the Primary Grades. Boston, MA: Allyn \& Bacon.

\section{Copyrights}

Copyright for this article is retained by the author(s), with first publication rights granted to the journal.

This is an open-access article distributed under the terms and conditions of the Creative Commons Attribution license (http://creativecommons.org/licenses/by/4.0/). 